\title{
Penggunaan Metode Peer Tutoring dengan Kassitu untuk Meningkatkan Motivasi dan Hasil Belajar IPA Fisika
}

\author{
Sujatmiani \\ SMP Negeri 5 Kepil \\ Surat-e: kiranakamila@gmail.com
}

Tujuan penelitian ini untuk meningkatkan motivasi dan hasil belajar menggunakan metode peer tutoriing dengan Kassitu. Pengumpulan data kuantitatif dengan soal pretest dan posttest sedangkan data kualitatif didapatkan melalui angket, dan lembar observasi. Data kuantitatif dianalisis dengan analisis deskriptif komparatif dengan melihat perbandingan nilai pre test dan pos test pra siklus, siklus I dan siklus 2. Data kualitatif dianalisis menggunakan analisis deskriptif kualitatif dengan mencari point penting dan informasi tambahan dari hasil observasi.

Motivasi belajar meningkat sebesar I I,78\% sedangkan Hasil belajar meningkat sebesar 17,89\%. Motivasi belajar siswa meningkat dilihat dari aktifitas kelompok dalam berdiskusi, mengerjakan soal latihan, tanya jawab bersama tutor, serta turnamen antar kelompok sehingga dapat disimpulkan bahwa metode peer tutoring dengan Kassitu dapat meningkatkan motivasi dan hasil belajar IPA

Kata kunci: peer tutoring, kassitu, motivasi belajar, hasil belajar

\section{Pendahuluan}

Ilmu Pengetahuan Alam seharusnya menjadi pelajaran yang menarik bagi peserta didik karena IPA berkaitan dengan diri sendiri serta lingkungannya. Namun kondisi di sekolah peneliti menunjukkan bahwa IPA, khususnya materi fisika dianggap sebagai pelajaran yang sulit. Hal ini ditunjukkan dengan hasil ulangan harian fisika dari tahun ke tahun yang kurang memuaskan. Pada tahun pelajaran 2014/ 2015 semester 2 didapatkan data rata- rata ketuntasan ulangan harian IPA hanya mencapai 39,I \%. Motivasi belajar siswa juga masih rendah, ditandai dengan banyaknya siswa yang terlambat masuk kelas, tidak mengerjakan tugas rumah, serta tidak antusias ketika guru mengajar. Kemampuan siswa yang heterogen menjadikan guru kesulitan dalam menyampaikan materi, siswa yang pandai akan bosan ketika materi sering diulang- ulang namun siswa yang kurang pandai akan ketinggalan ketika guru mengajar dengan cepat. Sehingga untuk mengatasi permasalahan yang ada, Peneliti akan menggunakan metode pembelajaran peer tutoring dengan kassitu pada kegiatan belajar mengajar IPA fisika di kelas VIII B SMP N 5 Kepil Kabupaten Wonosobo.

Peer Tutoring dikenal dengan pembelajaran teman sebaya atau antar peserta didik. Metode ini dilakukan dengan cara memberdayakan kemampuan peserta didik yang memiliki daya serap tinggi agar mengajarkan materi atau latihan kepada teman- temannya yang belum faham. Peer tutoring termasuk pembelajaran kooperatif. Ide utama pembelajaran kooperatif yaitu siswa bekerja sama dan bertanggung jawab pada kemajuan belajar temannya sehingga dapat membantu individu menjalani proses pembelajaran yang lebih positif dari pada ketika siswa hanya mengerjakannya sendiri [I][2].

Beberapa penelitian membuktikan bahwa pembelajaran kooperatif dengan tutor sebaya efektif untuk meningkatkan motivasi belajar siswa [3][4]. Tutor sebaya dapat meningkatkan hasil belajar siswa [5][6].

\section{Kajian Pustaka}

\section{Motivasi Belajar}

Motivasi didefinisikan sebagai suatu proses usaha yang menghasilkan intensitas, arah dan ketekunan individual dengan menyediakan kondisi tertentu sehingga seseorang mau melakukan sesuatu untuk mencapai suatu tujuan [7][8]. Motivasi punya peranan besar dalam keberhasilan seseorang dalam belajar [9]. 


\section{Hasil Belajar}

Hasil Belajar adalah pola perbuatan, nilai, pengertian, sikap, apresiasi, dan ketrampilan yang merupakan hasil dari interaksi belajar dan mengajar [I0][II].

\section{Metode Peer Tutoring}

Peer tutoring (Tutor sebaya) adalah teman sebaya yang lebih pandai memberikan bantuan belajar untuk mengatasi kesulitan siswa lain dalam memahami pelajaran sehingga setiap anggota belajar bersama dan saling belajar dari anggota yang lain [12][13][14]. Interaksi dengan teman sebaya dapat mendukung perkembangan kognitif, sebab terdapat layanan dari teman sebaya sebagai nara sumber bagi teman lainnya [I5][I6]. Dalam peer tutoring siswa yang berperan sebagai tutor bertugas menjelaskan materi atau penyelesaian soal kepada anggota kelompok/tutee. Keakraban tutor dan anggotanya menyebabkan terjalinnya hubungan antar pribadi yang positif dengan menerapkan bimbingan antar teman sehingga tercipta lingkungan yang dapat membangun motivasi belajar siswa dan pada akhirnya berpengaruh terhadap hasil belajar [17][18]. Hasil belajar bisa diperoleh dari sharing antar teman dan antara yang tahu ke yang belum tahu. Pelajar yang lambat bisa bertanya kepada tutor untuk mengatasi kesulitan mereka dengan lebih nyaman [19].

Dari beberapa pengertian diatas dapat dirangkum bahwa Peer tutoring adalah metode pembelajaran berkelompok dengan anggota yang heterogen dimana setiap kelompok memiliki satu peserta didik yang lebih pandai yang berperan sebagai tutor untuk memberi bimbingan kepada temantemannya dalam satu kelompok.

Kassitu merupakan akronim dari Kartu soal, motivasi dan turnamen. Turnamen dilaksanakan setelah kelompok selesai belajar materi tertentu. Turnamen akan membuat peserta didik lebih semangat dalam belajar dan berlomba untuk menjadi kelompok terbaik. "Murid akan termotivasi secara intrinsik oleh pengalaman- pengalaman yang memberikan tantangan, mendorong perasaan otonomi peserta didik, membangkitkan rasa ingin tahu, melibatkan kreativitas dan fantasi, memberikan investasi pribadi” [20]. Dengan turnamen diharapkan motivasi belajar peserta didik akan meningkat sehingga dapat meningkatkan hasil belajar peserta didik

\section{Metode Penelitian}

\section{Subjek Penelitian}

Penelitian ini dilaksanakan di kelas VIII B SMP Negeri 5 Kepil Kabupaten Wonosobo Jawa Tengah

\section{Rancangan Penelitian}

Penelitian ini merupakan Penelitian Tindakan Kelas (classroom action research). PTK meliputi empat tahapan utama yakni perencanaan, pelaksanaan tindakan, observasi, dan refleksi. Keempat tahap tersebut tergabung dalam suatu siklus, dan siklus tersebut dapat diulangi lagi ketika hasil dalam siklus sebelumnya dianggap belum berhasil [2I][22]

Penelitian ini dilaksanakan dalam 2 siklus. Masingmasing siklus sebanyak $2 \mathrm{x}$ pertemuan menggunakan metode peer tutoring dengan kassitu.

\section{Instrumen Penelitian}

\section{a. Angket}

Motivasi belajar siswa diungkap dengan angket yang dikembangkan berdasarkan indikator yang telah ditetapkan.

b. Lembar Observasi pembelajaran

Meliputi lembar observasi motivasi siswa dan lembar observasi pembelajaran guru.

c. Butir Soal

Berupa soal pre test dan post tes, Kartu soal untuk belajar dalam kelompok dan kartu soal untuk turnamen.

\section{Validasi Data}

Data divalidasi dengan trianggulasi sumber dan trianggulasi metode. Trianggulasi sumber berupa kolaborasi dengan teman sejawat sedangkan trianggulasi metode menggunakan teknik dan alat pengumpul data.

\section{Analisis Data}

Data kuantitatif dianalisis dengan analisis deskriptif komparatif dengan melihat perbandingan nilai pre test dan posttes sedangkan data kualitatif dianalisis dengan analisis deskriptif kualitatif dengan mencari poin penting dan informasi tambahan dari hasil observasi

\section{Hasil Penelitian dan Pembahasan}

\section{Siklus 1}

\section{Tindakan}

Pertemuan pertama dilaksanakan pembelajaran sesuai dengan RPP yaitu dengan metode peer tutoring, apabila dalam membimbing kelompok tutor masih mengalami kesulitan, tutor bisa bertanya kepada guru. Pertemuan kedua dilaksanakan turnamen antar kelompok.

\section{Pengamatan/ Observasi \\ 2.I. Deskripsi Hasil Belajar}


Tabel I. Nilai Pre test dan Post test siklus I

\begin{tabular}{clcc}
\hline NO & \multicolumn{1}{c}{ Uraian } & Pre Test & Post Test \\
\hline I & Nilai Terendah & 7 & 27 \\
2 & Nilai Tertinggi & 60 & 100 \\
3 & Nilai Rata- rata & 30,04 & 77,85 \\
4 & \% Ketuntasan & $0 \%$ & $63 \%$ \\
\hline
\end{tabular}

2.2. Deskripsi Motivasi belajar

Dari angket didapatkan bahwa motivasi belajar rata- rata dalam satu kelas 69,8I \% termasuk kategori tinggi.

Tabel 2. motivasi belajar siklus I

\begin{tabular}{clcc}
\hline No & \multicolumn{1}{c}{ Kategori } & Frekuaensi & Prosentase \\
\hline I & Sangat Tinggi( 80\%-100\%) & I & $4 \%$ \\
2 & Tinggi (66\%-79\%) & 19 & $70 \%$ \\
3 & Sedang (56\%-65\%) & 7 & $26 \%$ \\
4 & Rendah (40\%-55\%) & 0 & $0 \%$ \\
5 & Sangat Rendah (0\%-39\%) & 0 & $0 \%$ \\
& Jumlah & 27 & $100 \%$ \\
\hline
\end{tabular}

\section{Refleksi}

a) Pada saat pembelakan tutor ada I tutor yang kurang memperhatikan tapi sudah sibuk mengerjakan soal.

b) Waktu dalam berdiskusi kelompok masih kurang

c) Guru tidak menjelaskan materi secara klasikal.

d) Pada saat turnamen masih kurang teratur.

e) Lembar jawaban turnamen terpisah untuk setiap nomor sehingga banyak siswa yang lupa menuliskan nomor soal maupun nomor siswa, hal ini juga menyulitkan guru dalam mengoreksi lembar jawab turnamen

f) Pada meja turnamen tidak diberi kursi sehingga siswa kurang nyaman dalam mengerjakan soal

g) Pada meja turnamen tidak terdapat nama kelompok sehingga ada kelompok yang salah tempat

\section{Siklus 2}

\section{Tindakan}

Pembelajaran dilaksanakan menggunakan metode peer tutoring seperti siklus I dengan beberapa perbaikan, salah satunya ditambahnya waktu untuk diskusi kelompok, serta perbaikan aturan turnamen.

\section{Pengamatan/ Observasi}

\section{I. Deskripsi Hasil Belajar}

Setelah siklus 2 sudah terdapat peningkatan Hasil belajar dibandingkan siklus I.
Tabel 3. Nilai Pre test dan Post test siklus 2

\begin{tabular}{cccc}
\hline NO & Uraian & Pre Test & Post Test \\
\hline I & Nilai Terendah & 20 & 40 \\
2 & Nilai Tertinggi & 77 & 100 \\
3 & Nilai Rata- rata & 37,04 & 78,37 \\
4 & \% Ketuntasan & $3,7 \%$ & $67 \%$ \\
\hline
\end{tabular}

\subsection{Deskripsi Motivasi belajar}

Dari angket didapatkan bahwa motivasi belajar rata- rata dalam satu kelas 72,01\%, termasuk kategori tinggi.

Tabel 4. Motivasi belajar siklus 2

\begin{tabular}{clcc}
\hline No & Kategori & Frekuensi & Prosentase \\
\hline I & Sangat Tinggi (80\%-I00\%) & 2 & $7 \%$ \\
2 & Tinggi (66\%-79\%) & 19 & $70 \%$ \\
3 & Sedang (56\%-65\%) & 6 & $23 \%$ \\
4 & Rendah (40\%-55\%) & 0 & $0 \%$ \\
5 & Sangat Rendah (0\%-39\%) & 0 & $0 \%$ \\
& Jumlah & 27 & $100 \%$ \\
\hline
\end{tabular}

\section{Refleksi}

a) Pada saat belajar bersama antara tutor dengan guru semua tutor memperhatikan dan bertanya jawab atas penyelesaian soal.

b) Waktu dalam berdiskusi kelompok sudah cukup sehingga semua siswa cukup menguasai materi atau soal yang harus dipelajari dalam kelompok.

c) Guru terlebih dahulu memberikan materi secara klasikal sehingga menambah pemahaman siswa

d) Pada saat turnamen sudah lebih teratur karena kelompok siswa memulai setiap soal bersama- sama

e) Lembar jawaban turnamen dijadikan satu untuk setiap kelompok sehingga memudahkan guru dalam mengoreksi lembar jawab turnamen

f) Pada meja turnamen diberi kursi sehingga siswa lebih nyaman dalam mengerjakan soal

g) Pada meja turnamen terdapat nama kelompok sehingga tidak ada kelompok yang salah tempat

\section{Pembahasan}

\section{a. Motivasi Belajar}

Perbandingan Prosentase motivasi belajar siswa dari pra siklus, siklus I dan siklus 2 dapat diamati dari histogram berikut: 


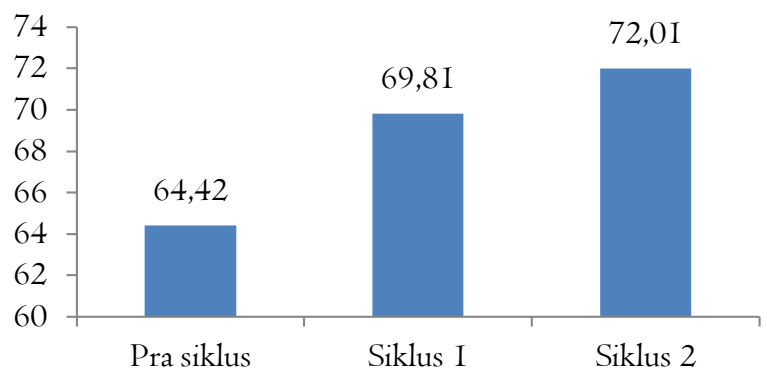

Gambar I. Histogram perbandingan motivasi belajar

\section{b. Hasil Belajar}

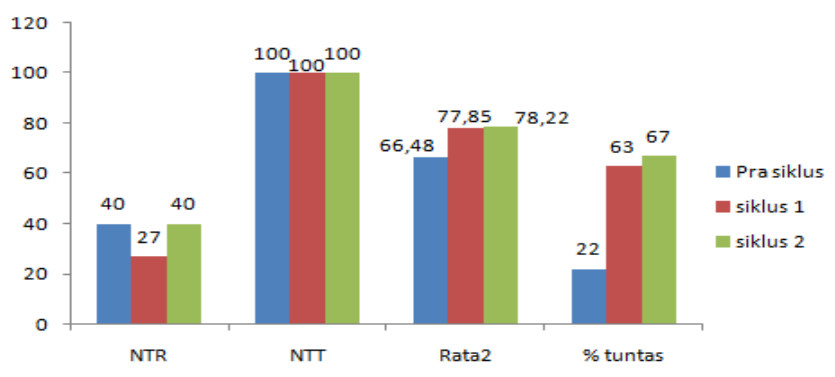

Gambar 2. Histogram Perbandingan hasil belajar siswa

Dari histogram tersebut dapat diamati bahwa dari pra siklus ke siklus 2 terdapat peningkatan motivasi dan hasil belajar siswa.

\section{Kesimpulan}

Metode pembelajaran Peer Tutoring dengan Kassitu dapat meningkatkan motivasi dan hasil belajar IPA di kelas VIIIB SMP N 5 Kepil.

\section{Ucapan Terimakasih}

Ucapan terima kasih diberikan kepada rekan kolaborator, kameraman dan teman sejawat serta semua pihak yang telah memberi dukungan untuk penelitian ini.

\section{Kepustakaan}

[I] Trianto, 20I4. Mendesain Model Pembelajaran Inovatif, Progresif, dan Kontekstual. Jakarta: Prenada Media Group.

[2] Huda Miftahul. 2013. Model- Model Pengajaran dan Pembelajaran. Malang: Pustaka Pelajar.

[3] Evita Rahayu dan Sukanti. 2013. Penerapan Metode Pembelajaran Kooperatif dengan bantuan Tutor Sebaya untuk meningkatkan
Motivasi Belajar Akuntansi. Yogyakarta: Jurnal Pendidikan Akuntansi Indonesia, Vol.XI, No. 2, tahun 2013 : 76-90.

[4] Siska Firmasari, YL Sukestiyarno, Sc.Mariani. 2013. Pengembangan bahan Ajar menggunakan Taksonomi SOLO Superitem dengan Tutor Sebaya Berbantuan WinGeom. Semarang: Unnes Journal of Mathematics Education Research: UJMER 2 (I) (2013):I84-I89.

[5] Istianah Qudsi FT. 20I4.Pembelajaran Tutor Sebaya Materi Besaran dan Satuan Fisika. Jawa Timur: Dinamika Vol.4,No.3, Januari 2014 : I-IO.

[6] Arjanggi R dan Suprihatin T. 2010. Metode Pembelajaran Tutor Teman Sebaya Meningkatkan Hasil Belajar Berdasar Regulasi Diri. Semarang: Makara, Sosial Humanora, Vol. I4, No. 2, Desember 2010: 9I-97.

[7] Koswara Deni dan Halimah. 2008. Bagaimana Menjadi Guru Kreatif. Bandung: Pribumi Mekar

[8] Sardiman, A.M. 20II. Interaksi dan Motivasi Belajar Mengajar. Jakarta: Rajawali Press.

[9] Uno Hamzah. 2012. Teori Motivasi dan Pengukurannya. Jakarta: Bumi Aksara.

[I0] Suprijono Agus. 2009. Cooperative Learning. Yogyakarta: Pustaka Pelajar.

[II] Dimyati dan Mudjiono.2013. Belajar \& Pembelajaran. Jakarta: Rineka Cipta \& Depdikbud.

[I2] Brittany Hott and Jennifer Walker. 2012. Peer Tutoring. George Mason University Jasneen Sahni, Marymount University. CLD ( Council for Learning Diabilities).

[13] Warsono dan Hariyanto. 2012. Pembelajaran Aktif. Bandung. Remaja Rosdakarya.

[I4] Ningrum Pusporini Anggorowati.20II. Penerapan Model Pembelajaran Tutor Sebaya Pada Mata Pelajaran Sosiologi. Kudus: Jurnal Komunitas 3 (I) (201 I):I03-I20.

[I5] Allen Thurston, K. Van de Keere, K.J. Topping, W. Kosack, S.Gatt, J. Marscal, N. Mestdagh, D. Schmeinck, W. Sidor, K. Donnert. 2007. Peer learning in primary school science: Theoritical prespectives and implications for classroom practice. Elecrtonic Journal of Research in Educational Psychology, N. I3 Vol. 5(3) 2007. ISSN: 1696-2095. Pp:477-496.

[16] Fajar Sanubari, Sri Yamtinah, dan Tri Rejeki. 20I4. Penerapan Metode Pembelajaran Tutor Teman Sebaya dilengkapi dengan Media Interaktif Flash untuk meningkatkan Minat dan Prestasi Belajar Siswa kelas XI IPA I SMA Negeri I Sukoharjo Tahun Pelajaran 2013/20I4 pada Materi Larutang Penyangga. Surakarta: Jurnal Pendidikan Kimia (JPK), Vol. 3 No. 4 Tahun 2014 : I46I54.

[17] Tracey D Fox, Natasha B Vos and Johanna L Geldenhuys. 2007. The experience of cross-cultural peer teaching for a group of mathematics learners. Nelson Mandela Metropolitan University, Phythagoras 65, June, 2007, pp. 45-52.

[18] Chen, Ching, Liu, and Chang-Chen. 2010. A case study of peer tutoring program in higher education. Taiwan: Research in Higher Education Journal: I-IO.

[19] Ray(Arora) Suranjana, Ray Ujjani, Ray Manas Kanti. 2015. Peer Tutoring as a Remedial Measure for Slow Learners in a Medical School. Journal of Krishna Institute of Medical Sciences University ( JKIMSU), Vol.4,No. I, Jan-Mar 2015 : I30-I34.

[20] Eggen, Paul dan Kauchak, Don. 2012. Strategi dan Model Pembelajaran. Jakarta: PT.Indeks.

[2I] Subyantoro. 20I4. Penelitian Tindakan Kelas. Semarang: Duta Publishing Indonesia.

[22] Supardi dan Suhardjono. 2012. Strategi Menyusun Penelitian Tindakan Kelas. Jogjakarta: Andi Offset. 